\title{
PERAN PSIKIATER DALAM PEMBUKTIAN KEKERASAN PSIKIS PADA KORBAN TINDAK PIDANA KEKERASAN DALAM RUMAH TANGGA
}

\author{
Erwin Asmadi \\ Fakultas Hukum Universitas Muhammadiyah Sumatera Utara \\ Jl. Kapt. Mukhtar Basri No. 3 Medan \\ Email: erwinasmadi@umsu.ac.id
}

\begin{abstract}
Abstrak
Hubungan harmonis rumah tangga adalah impian setiap manusia. Namun dalam perjalanan bahtera rumah tangga, ada kendala seperti kekerasan. Jika kekerasan dilakukan secara fisik atau seksual, maka ada cedera atau tanda-tanda yang bisa dilihat secara kasat mata. Tetapi jika kekerasan tersebut menimpa seseorang secara psikologis, diperlukan pengetahuan khusus untuk mengidentifikasi adanya kekerasan psikologis yang diderita oleh korban kekerasan dalam rumah tangga. Makalah ini menguraikan peran penting psikiater dalam membuktikan kekerasan psikologis dalam tindak pidana kekerasan dalam rumah tangga. Berdasarkan ketentuan Pasal 184 ayat (1) huruf b KUHAP, peran psikiater yang memberikan informasi sebagai tenaga ahli ditempatkan sebagai tenaga ahli sehingga menjadi salah satu bukti. Peran lain, psikiater dapat menerbitkan visum et repertum yang dikenal di dunia psikiater sebagai visum et repertum pshiciatricum.
\end{abstract}

\section{Kata Kunci: Kekerasan, Psikis, Pembuktian, Keluarga}

\section{Abstract}

The harmonious relationship of the household is the dream of every human being. But in the journey of the household ark, there are obstacles such as violence. If the violence is carried out physically or sexually, then there are injuries or signs that can be seen in plain view. But if the violence hits someone psychologically, it requires special knowledge to identify the existence of psychological violence suffered by victims of domestic violence. This paper outlines the important role of psychiatrists in proving psychological violence in criminal acts of domestic violence. Based on the provisions of Article 184 paragraph (1) letter $b$ of the Criminal Procedure Code, the role of the psychiatrist who provides information as an expert is located as an expert so that it becomes one of the evidences. Another role, psychiatrists can publish Visum et Repertum known in the world of psychiatrists as Visum et Repertum Pshiciatricum.

\section{Keywords: Violence, Physic, Proof, Family}

\section{PENDAHULUAN}

Keutuhan dan kerukunan rumah tangga yang bahagia, aman, tenteram dan damai merupakan dambaan setiap orang dalam rumah tangga. Mewujudkan keutuhan dan kerukunan tersebut sangat tergantung pada setiap orang dalam lingkup rumah tangga, terutama kadar kualitas perilaku dan pengendalian diri setiap orang dalam lingkup rumah tangga tersebut. Keutuhan dan kerukunan rumah tangga dapat terganggu jika kualitas perilaku dan pengendalian diri tidak dapat dikontrol, yang pada akhirnya dapat terjadi Kekerasan Dalam 
DE LEGA LATA

Jurnal Ilmu Hukum

FAKULTAS HUKUM UMSU
Peran Psikiater Dalam...(Erwin Asmadi)

Volume 3 Nomor 1, Januari-Juni 2018, 39-51

DOI: https://doi.org/10.30596/dll.v3i1.3136

Rumah Tangga (KDRT) sehingga timbul ketidakamanan atau ketidakadilan terhadap orang yang berada dalam lingkup rumah tangga.

Ketidakamanan atau ketidakadilan yang ditimbulkan akibat dari kekerasan dalam rumah tangga itu sendiri dapat mencakup beberapa hal yaitu penderitaan atau penelantaran rumah tangga, kekerasan secara fisik, kekerasan seksual bahkan kekerasan secara psikis yang dapat menimbulkan hal-hal yang melanggar hukum dalam kehidupan rumah tangga. Tindak penelantaran rumah tangga, kekerasan fisik, kekerasan seksual dan kekerasan psikis dalam rumah tangga telah diatur dalam Undang-undang Nomor 23 Tahun 2004 tentang Penghapusan Kekerasan Dalam Rumah Tangga (UU PKDRT).

Akibat dari KDRT tersebut menimbulkan korban kekerasan fisik, kekerasan seksual maupun kekerasan psikis, maka dalam hal ini wajib di proses secara hukum dan wajib untuk dibuktikan kebenaran yang dialami oleh korban itu sendiri, dan proses hukum yang dijalankan harus sesuai dengan proses hukum yang berlaku di Indonesia.

Berdasarkan UU PKDRT Pasal 7 menyatakan bahwa kekerasan psikis yang terjadi lebih dominan mengarah kepada gangguan tekanan batin atau jiwa seseorang, sehingga mengakibatkan ketakutan, hilangnya rasa percaya diri, hilangnya kemampuan untuk bertindak serta menimbulkan rasa tak berdaya. Menentukan dan membuktikan korban mengalami suatu kekerasan psikis merupakan suatu hal yang sulit untuk dibuktikan, karena tekanan psikis bukanlah hal yang bisa dialami seseorang dalam waktu yang singkat. Orang yang sampai mengalami tekanan psikis biasanya telah mendapatkan hal-hal buruk yang mengganggu psikis/jiwa/batinnya secara terus menerus dan berangsur lama (dalam waktu yang tidak singkat).

Kekerasan psikis adalah kekerasan yang berbeda dengan kekerasan fisik atau seksual, karena kekerasan fisik dan seksual yang pastinya dapat ditandai dengan mudah seperti luka atau lebam dan korban yang mengalami kekerasan fisik atau seksual sudah pasti mengalami kekerasan psikis, namun tidak sebaliknya dengan kekerasan psikis, orang yang mengalami kekerasan psikis belum tentu mengalami kekerasan fisik maupun seksual.

KDRT secara psikis merupakan suatu tindak pidana yang harus dilakukan upaya atau proses di tingkat penyidikan untuk membuktikan bahwa seorang korban kekerasan psikis telah mengalami atau memang benar mengalami kekerasan psikis tersebut. Membuktikan KDRT secara psikis mempunyai proses yang khusus dibandingkan dengan KDRT secara fisik maupun seksual, karena KDRT secara psikis ini harus dibantu oleh seorang Dokter atau ahli psikiater dalam proses pembuktiannya untuk menentukan benar atau tidaknya seorang korban mengalami suatu tindak kekerasan psikis.

Dokter atau ahli psikiater adalah profesi Dokter spesialistik yang memiliki spesialisasi dalam diagnosis dan penanganan gangguan emosional. Psikiater tidak hanya menangani masalah gangguan jiwa berat, tetapi juga ringan. Dokter atau ahli psikiater tersebut akan menggunakan ilmu psikiatri (ilmu kedokteran jiwa) yang merupakan suatu ilmu yang mempelajari tingkah laku manusia, dalam hal-hal abnormal (patologis) dengan berbagai motifnya (R. Soeparmono, 2016, h. 28).

Orang yang mengalami suatu gangguan jiwa dilihat dari segi kejiwaan, maka orang tersebut mengalami suatu gangguan jiwa atau penyakit, suatu penjelmaan (manifestasi) fungsi 
Jurnal Ilmu Hukum

FAKULTAS HUKUM UMSU
Peran Psikiater Dalam...(Erwin Asmadi)

Volume 3 Nomor 1, Januari-Juni 2018, 39-51

DOI: https://doi.org/10.30596/dll.v3i1.3136

kejiwaan (ratio atau emosi) yang dilakukan di luar batas normal dan tanpa sadar. Akibat dari kekerasan psikis tersebut bisa mengakibatkan kelainan jiwa ringan, misalnya adanya kelainan jiwa (kepribadian), karena gangguan mental, goncangan mental atau stress ringan merasa tidak aman, depresi mental, histerik atau histeria dan lain-lain (R. Soeparmono, 2016, h. 28).

Manifestasi kelainan jiwa akibat dari kekerasan atau tekanan psikis dimaksud dalam hukum perlu diukur dengan parameter atau standar yang jelas agar dapat dijadikan pembuktian suatu perkara. Pembuktian tersebut memerlukan alat-alat bukti sebagaimana disebutkan dalam Pasal 184 Ayat 1 Undang-undang Nomor 8 Tahun 1981 tentang Hukum Acara Pidana (KUHAP) yang menyatakan bahwa "alat bukti yang sah ialah keterangan saksi, keterangan ahli, surat, petunjuk, dan keterangan terdakwa".

Proses untuk membuktikan korban kekerasan psikis membutuhkan seorang Dokter Psikiater sebagai ahli (keterangan ahli) sebagai salah satu alat bukti yang sah seperti yang disebutkan di atas. Hal ini diatur pada Pasal 120 KUHAP yang menjelaskan apabila penyidik mengangap perlu keterangan ahli atau orang yang memiliki keahlian khusus (lebih dahulu disumpah) memberikan keterangan menurut pengetahuannya (H.S. Brahmana. 2015: 71).

Berdasarkan uraian tersebut diatas, maka peran psikiater dalam pembuktian kekerasan psikis pada korban tindak pidana kekerasan dalam rumah tangga menjadi penting untuk di bahas, yang menjadi pokok pembahasan dalam penulisan ini adalah bagaimana bentuk dan ruang lingkup kekerasan dalam rumah tangga menurut UU PKDRT, bagaimana peran psikiater dalam pembuktian kekerasan psikis korban tindak pidana kekerasan dalam rumah tangga, guna mengetahui peran psikiater dalam pembuktian kekerasan psikis pada korban tindak pidana kekerasan dalam rumah tangga.

\section{METODE PENELITIAN}

Jenis penelitian hukum dapat dibedakan menjadi penelitian hukum normatif dan penelitian hukum empiris/sosiologis. Penelitian hukum normatif merupakan penelitian yang datanya bersumber pada data sekunder dan berhubung data penelitian ini adalah data sekunder, maka termasuk dalam jenis penelitian hukum normatif. Sifat penelitian ini adalah deskriptif, yang bertujuan untuk memberikan gambaran tentang gejala-gejala sosial yang tentang peran psikiater dalam pembuktian kekerasan psikis pada tindak pidana kekerasan dalam rumah tangga. Sumber data penelitian berupa bahan hukum primer, bahan hukum sekunder dan bahan hukum tersier. Metode pengumpulan data dilakukan menggunakan teknik studi dokumen, yang dianalisis dengan menggunakan teknik analisis kualitatif.

\section{PEMBAHASAN}

\section{Bentuk dan Ruang Lingkup Kekerasan Dalam Rumah Tangga (KDRT) menurut UU PKDRT}

Kekerasan Dalam Rumah Tangga (KDRT) adalah setiap perbuatan terhadap perempuan atau laki-laki, baik dari anak-anak, orang dewasa sampai dengan orang tua, yang berakibat timbulnya kesengsaraan atau penderitaan secara fisik, seksual, psikologis, dan/atau penelantaran rumah tangga termasuk ancaman untuk melakukan perbuatan, pemaksaan, atau perampasan kemerdekaan secara melawan hukum dalam lingkup rumah tangga (Badriyah Khaleed, 2015, h. 1). 
DE LEGA LATA

Jurnal Ilmu Hukum

FAKULTAS HUKUM UMSU
Peran Psikiater Dalam...(Erwin Asmadi)

Volume 3 Nomor 1, Januari-Juni 2018, 39-51

DOI: https://doi.org/10.30596/dll.v3i1.3136

Dilihat dari segi subyek dan obyeknya, maka KDRT dapat terjadi dengan beberapa konteks antara lain:

a. Kekerasan suami terhadap istri

b. Kekerasan istri terhadap suami

c. Kekerasan orang tua kepada anak-anak

d. Kekerasan anak kepada orang tua

e. Kekerasan terhadap pembantu rumah tangga.

Setiap orang dilarang melakukan kekerasan dalam rumah tangga terhadap orang dalam lingkup rumah tangganya. Kekerasan yang terjadi di dalam rumah tangga, menurut Pasal 5 UU PKDRT, meliputi:

a. Kekerasan fisik, berdasarkan Pasal 6 UU PKDRT kekerasan fisik adalah perbuatan yang mengakibatkan rasa sakit, jatuh sakit atau luka berat.

b. Kekerasan psikis, berdasarkan Pasal 7 UU PKDRT kekerasan psikis adalah perbuatan yang mengakibatkan ketakutan, hilangnya rasa percaya diri, hilangnya untuk bertindak, rasa tidak berdaya dan/attau penderitaan psikis berat pada seseorang.

c. Kekerasan seksual, berdasarkan Pasal 8 UU PKDRT kekerasan seksual meliputi:

1) Pemaksaan hubungan seksual yang dilakukan terhadap orang yang menetap dalam lingkup rumah tangga tersebut.

2) Pemaksaan hubungan seksual terhadap salah seorang dalam ingkup rumah tangga dengan orang lain untuk tujuan komersial dan/atau tujuan tertentu.

d. Penelantaran Rumah tangga, berdasarkan Pasal 9 UU PKDRT penelantaran rumah tangga meliputi:

1) Setiap orang dilarang menelantarkan orang dalam lingkup rumah tangganya, padahal menurut hukum yang berlaku baginya atau karena persetujuan atau perjanjian ia wajib memberikan kehidupan, perawatan atau pemeliharaan kepada orang tersebut.

2) Penelantaran juga berlaku bagi setiap orang yang mengakibatkan ketergantungan ekonomi dengan cara membatasi dan/atau melarang untuk bekerja yang layak di dalam atau di luar sehingga korban berada di bawah kendali orang tersebut.

Berdasarkan ketentuan Pasal 2 UU PKDRT, maka lingkup rumah tangga meliputi:

a. Suami, istri, dan anak; Suami adalah pria yang menjadi pasangan hidup resmi seorang wanita (istri), istri adalah wanita (perempuan) yang telah menikah atau bersuami dan anak adalah seorang yang dilahirkan dari perkawinan antara seorang perempuan dengan seorang laki-laki dengan tidak menyangkut bahwa seseorang yang dilahirkan oleh wanita meskipun tidak pernah melakukan pernikahan tetap dikatakan anak.

b. Orang yang mempunyai hubungan keluarga dengan orang yang dimaksud pada huruf a karena hubungan darah, perkawinan, persusuan, pengasuhan, dan perwalian, yang menetap dalam rumah tangga; dan/atau

c. Orang yang bekerja membantu rumah tangga dan menetap dalam rumah tangga tersebut. Orang yang bekerja dipandang sebagai anggota keluarga dalam jangka waktu selama berada dalam rumah tangga yang bersangkutan.

Perbuatan kekerasan yang dimaksud disini adalah sebuah usaha yang dilakukan oleh pasangan, baik laki-laki maupun perempuan, untuk mengambil alih posisi dominan dalam 
Jurnal Ilmu Hukum

FAKULTAS HUKUM UMSU
Peran Psikiater Dalam...(Erwin Asmadi)

Volume 3 Nomor 1, Januari-Juni 2018, 39-51

DOI: https://doi.org/10.30596/dll.v3i1.3136

sebuah keluarga. Pelaku berupaya untuk mengambil kontrol dalam rumah tangga baik itu berbentuk hak, kebebasan, atau lain-lainnya, ini tentunya tidak hanya dalam bentuk fisik saja melainkan bisa juga dengan cara lain. Cara yang lain misalnya ketika suami melarang istri dalam bekerja atau sebaliknya. Hal ini menyebabkan istri memiliki ketergantungan secara ekonomi pada pasangan. Itu sudah termasuk KDRT, atau seorang istri dipaksa bekerja untuk memenuhi kebutuhan sendiri tanpa diberikan nafkah oleh suami, itu merupakan KDRT (Badriyah Khaleed, 2015, h. 2).

Contoh lainnya masalah keuangan yang sebenarnya hasil kerja sendiri dan atau uang tabungan milik sendiri dirampas oleh pasangan. Hal itu termasuk kekerasan dalam rumah tangga. Hal ini termasuk kedalam kekerasan karena sudah mengambil hak yang tidak semestinya. Hal yang menyangkut kekerasan psikis atau mental, salah satu contohya ketika pasangan bicara dengan gaya yang terlalu berlebihan dan sehingga menyakiti hati pasangannya sendiri itu adalah kekerasan psikis. Apalagi kalau sampai dalam berbagai aktivitas, pasangan selalu berada dalam keadaan posisi yang disalahkan, jelas-jelas itu termasuk dalam kekerasan (Badriyah Khaleed, 2015h. 2).

Hampir kebanyakan pelaku KDRT atau korban KDRT enggan meninggalkan pasangan dan memilih untuk tetap bersama dengan pasangannya, padahal sering melakukan kekerasan atau mengalami penderitaan yang berat. Masalahnya, pelaku kekerasan sering kali bukanlah orang asing, justru orang yang sangat dipercaya atau yang sangat disayangi korbannya, dan ketika kekerasan terjadi, si korban akan mengangap ini wajar (Badriyah Khaleed, 2015h. 3).

Kekerasan psikis adalah perbuatan yang mengakibatkan ketakutan, hilangnya rasa percaya diri, hilangnya kemampuan untuk bertindak, rasa tidak berdaya, dan/atau penderitaan psikis berat pada seseorang (Badriyah Khaleed, 2015, h. 19). Hal ini sudah diatur dalam Pasal 7 UU PKDRT menjelaskan bahwa dampak kekerasan psikis yang mengakibatkan ketakutan, hilangnya rasa percaya diri, hilangnya kemampuan untuk bertindak, rasa tidak berdaya, dan/atau penderitaan psikis berat pada seseorang.

Kekerasan psikis ini bisa menimpa atau dialami oleh siapupun baik pada perempuan atau laki-laki, mulai dari anak kecil, orang dewasa bahkan orang tua, dimana kekerasan psikis ini memiliki dampak yang berbeda dengan bentuk kekerasan lain karena dampaknya lebih banyak tidak terlihat secara kasat mata seperti halnya kekerasan seksual dan kekerasan fisik yang bisa ditandai dengan sakit fisik atau cukup ditandai adanya luka, lebam-lebam atau memar pada bagian tubuh tertentu. Namun tidak dengan kekerasan psikis, salah satu hasilnya adalah penjabaran perilaku konkret yang umumnya ditampilkan korban sebagai perwujudan dampak psikis dari kekerasan yang ia alami. Ketakutan, hilangnya rasa percaya diri, hilangnya kemampuan untuk bertindak, rasa tidak berdaya, dan/atau penderitaan psikis berat dapat tampil dalam perilaku-perilaku berikut ini:

a. Kehilangan minat untuk merawat diri, yang tampil dalam perilaku menolak atau enggan makan/minum, makan tidak teratur, malas mandi atau berdandan, tampil berantakan seperti rambut kusut, pakaian awut-awutan; 
Jurnal Ilmu Hukum

FAKULTAS HUKUM UMSU

b. Kehilangan minat untuk berinteraksi dengan orang lain, yang tampil dalam perilaku mengurung diri di kamar, tidak mau berhubungan dengan orang lain, cenderung diam, dan enggan bercakap-cakap;

c. Perilaku depresif, tampil dalam bentuk pandangan mata kosong seperti menatap jauh ke depan, murung, banyak melamun, mudah menangis, sulit tidur atau sebaliknya terlalu banyak tidur, dan berpikir tentang kematian;

d. Terganggunya aktivitas atau pekerjaan sehari-hari, seperti sering menjatuhkan barang tanpa sengaja, kurang teliti dalam bekerja yang ditunjukkan dengan banyaknya kesalahan yang tidak perlu, sering datang terlambat atau tidak masuk bekerja, tugas-tugas terlambat tidak sesuai tenggat waktu, tidak menyediakan makanan untuk anak padahal sebelumnya hal-hal ini dilakukannya secara rutin;

e. Ketidakmampuan melihat kelebihan diri, tidak yakin dengan kemampuan diri, dan kecenderungan membandingkan diri dengan orang lain yang dianggapnya lebih baik. Contohnya menganggap diri tidak memiliki kelebihan meski fakta yang ada menunjukkan hal sebaliknya, atau sering bertanya apakah yang ia lakukan sudah benar atau belum;

f. Kehilangan keberanian untuk melakukan tindakan yang ditunjukkan dengan tidak berani mengungkapkan pendapat atau tidak berani mengingatkan pelaku jika bertindak salah;

g. Stres pasca trauma, yang tampil dalam bentuk mudah terkejut, selalu waspada; sangat takut bila melihat pelaku, orang yang mirip pelaku, benda-benda atau situasi yang mengingatkan akan kekerasan, gangguan kilas balik (flash back) seperti tiba-tiba disergap bayangan kejadian yang telah dialami, mimpi-mimpi buruk dan atau gangguan tidur;

$\mathrm{h}$. Kebingungan-kebingungan dan hilangnya orientasi, yang tampil dalam bentuk merasa sangat bingung, tidak tahu hendak melakukan apa atau harus bagaimana melakukannya, seperti orang linglung, bengong, mudah lupa akan banyak hal, terlihat tidak peduli pada keadaan sekitar, tidak konsentrasi bila diajak berbicara;

i. Menyakiti diri sendiri atau melakukan percobaan bunuh diri;

j. Perilaku berlebihan dan tidak lazim seperti tertawa sendiri, bercakap-cakap sendiri, terus berbicara dan sulit dihentikan, pembicaraan kacau; melantur, berteriak-teriak, terlihat kacau tak mampu mengendalikan diri, berulang-ulang menyebut nama tertentu, misalnya nama pelaku tanpa sadar;

k. Perilaku agresif, seperti menjadi kasar atau mudah marah terhadap anak/pekerja rumah tangga/staf atau rekan kerja, membalas kekasaran pelaku seperti mengucapkan kata-kata kasar, banyak mengeluhkan kekecewaan terhadap pelaku;

1. Sakit tanpa ada penyebab medis (psikosomatis), seperti infeksi lambung, gangguan pencernaan, sakit kepala, namun Dokter tidak menemukan penyebab medis, mudah merasa lelah, seperti tidak bertenaga, dan pegal/sakit/ngilu, tubuh sering gemetar;

m. Khusus pada anak, dampak psikis muncul dalam bentuk:

1) Mundur kembali ke fase perkembangan sebelumnya seperti kembali mengompol, tidak berani lagi tidur sendiri, kembali ingin terus berdekatan dengan orang lain yang dirasa memberi rasa aman, harus selalu ditemani, 
Jurnal Ilmu Hukum

FAKULTAS HUKUM UMSU
Peran Psikiater Dalam...(Erwin Asmadi)

Volume 3 Nomor 1, Januari-Juni 2018, 39-51

DOI: https://doi.org/10.30596/dll.v3i1.3136

2) Gangguan perkembangan bahasa seperti keterlambatan perkembangan bahasa, gangguan bicara seperti gagap, dan

3) Depresi yang tampil dalam bentuk perilaku menolak ke sekolah; prestasi menurun; tidak dapat mengerjakan tugas sekolah atau pekerjaan rumah dengan baik yang ditandai dengan banyaknya kesalahan, kurangnya perhatian pada tugas atau pada penjelasan yang diberikan orang tua/guru, dan berbagai keluhan fisik.

Gambaran dampak kekerasan psikis di atas perlu dipahami dalam arti ada perubahan perilaku dari yang tadinya tidak pernah atau hanya sedikit ditampilkan menjadi mulai ditampilkan atau sering tampil pada diri korban. Untuk menentukan seseorang mengalami kekerasan psikis bisa dipelajari dengan ilmu psikiatri (ilmu kedokteran jiwa) yang merupakan suatu ilmu yang mempelajari tingkah laku manusia, dalam hal-hal abnormal dengan berbagai motifnya. Dari segi kejiwaan, maka orang tersebut mengalami suatu gangguan jiwa atau penyakit, suatu penjelmaan (manifestasi) fungsi kejiwaan (ratio atau emosi) yang dilakukan di luar batas normal dan tanpa sadar. Akibat dari kekerasan psikis tersebut bisa mengakibatkan kelainan jiwa ringan, misalnya adanya kelainan jiwa (kepribadian), karena gangguan mental, goncangan mental atau stress ringan merasa tidak aman, depresi mental, histerik atau histeria dan lain-lain (R. Soeparmono, 2016, h. 28).

Orang yang menggunakan ilmu kedokteran jiwa ini disebut sebagai Dokter Psikiater atau ahli psikiater yang merupakan profesi Dokter spesialistik yang memiliki spesialisasi dalam diagnosis dan penanganan gangguan emosional yang menangani masalah gangguan jiwa berat maupun ringan dengan menggunakan ilmu psikiatri (ilmu kedokteran jiwa).

Kaitan antara Psikiatri (Ilmu Kedokteran Jiwa) dan Hukum, kedua-duanya menghadapi dan menanggulangi tingkah laku manusia, psikiatri lebih banyak daripada hukum. Psikiatri mencari dan menentukan tenaga-tenaga dan daya-daya yang mengakibatkan perubahanperubahan, penyimpangan-penyimpangan (deviasi-deviasi) tingkah laku dan berusaha bagaimana caranya untuk mengalihkan dan mengubahnya, sehingga menuju kepada hubungan antarpribadi yang jelas, tenang dan baik, kepada tujuan-tujuan yang lebih konstruktif dan lebih terisolasi, hukum lebih banyak menghadapi kontrol sosial dan tingkah laku (Hasan Basri Saanin, 1982, h. 13).

Sesungguhnya kedua disiplin ini menghadapi dua segi tingkah laku yang sangat berlainan, kedua-duanya mungkin memiliki banyak titik persamaan, karena keduanya mendekati masalah-masalah tingkah laku dari segi-segi yang sangat berlainan, tidaklah mengherankan, bahwa kadang-kadang akan dijumpai perbedaan-perbedaan dalam pandangan, tekanan dan pendapat (Hasan Basri Saanin, 1982, h. 13).

\section{Peran Psikiater dalam Pembuktian Kekerasan Psikis Korban Tindak Pidana Kekerasan dalam Rumah Tangga}

Rangkaian berikutnya adalah pembuktian. Pasal 183 KUHAP pada intinya menegaskan tidak seorang pun dapat dijatuhi pidana, kecuali apabila pengadilan, karena alat pembuktian yang sah menurut undang-undang, mendapat keyakinan bahwa seseorang yang dianggap dapat bertanggung jawab, telah bersalah atas perbuatan yang didakwakan atas dirinya (Andi Sofyan dan Abdul Asis, 2014, h. 230). 
DE LEGA LATA

Jurnal Ilmu Hukum

FAKULTAS HUKUM UMSU
Peran Psikiater Dalam...(Erwin Asmadi)

Volume 3 Nomor 1, Januari-Juni 2018, 39-51

DOI: https://doi.org/10.30596/dll.v3i1.3136

Kata “ Kata 'pembuktian' berasal dari kata dasar 'bukti' artinya 'sesuatu yang menyatakan kebenaran suatu peristiwa', kemudian mendapat awalan 'pem' dan akhiran 'an', maka pembuktian artinya 'proses perbuatan, cara membuktikan sesuatu yang menyatakan kebenaran suatu peristiwa', demikian pula pengertian membuktikan yang mendapat awalan 'mem' dan akhiran 'an', artinya memperlihatkan bukti, meyakinkan dengan 'bukti'”' (Andi Sofyan dan Abdul Asis, 2014, h. 230).

Setelah memahami mengenai apa itu pembuktian, maka harus mengetahui pembahasan istilah lain dari pembuktian dengan segala aktivitasnya, mengetahui pengertian dari istilahistilah tersebut tentunya akan sangat membantu dalam memahami lingkup pembuktian dan urgensinya (Bambang Waluyo, 2014, h. 1). Kata membuktikan dalam arti konvensional, yaitu yang memberi kepastian, hanya saja bukan kepastian mutlak melainkan kepastian yang nisbih atau relatif, sifatnya yang mempunyai tingkatan-tingkatan (Andi Sofyan dan Abdul Asis, 2014, h. 231).

Alat bukti adalah alat-alat yang ada hubungannya dengan suatu tindak pidana, di mana alat-alat tersebut dapat digunakan sebagai bahan pembuktian. Alat-alat bukti adalah alat-alat bukti macam apa yang digunakan untuk menetapkan kebenaran dalam penuntutan pidana, dan alat-alat bukti yang ada dalam KUHAP adalah keterangan saksi, keterangan ahli, surat, petunjuk, dan keterangan terdakwa. Tujuan pembuktian adalah untuk dijadikan dasar dalam menjatuhkan putusan hakim kepada terdakwa tentang bersalah atau tidaknya sebagaimana yang telah didakwakan oleh penuntut umum (Andi Sofyan dan Abdul Asis, 2014, h. 231).

Keberadaan alat bukti dalam pembuktian memegang peranan penting guna terungkapnya kekerasan psikis. Indonesia menganut sistem pembuktian menurut undangundang secara negatif dan menurut Andi Hamzah sebagaimana dikutip Erwin Asmadi (2013, h. 70) dalam Bahasa Belanda dikenal dengan sebutan negatief wettelijke bewijsleer. Teori ini sebagai pengejawatahan dari muatan Pasal 183 KUHAP, sehingga menurut M. Yahya Harahap sebagaimana dikutip Erwin Asmadi (2013) mengandung makna bahwa untuk menjatuhkan pidana kepada terdakwa, harus):

a. kesalahannya terbukti dengan sekurang-kurangnya dua alat bukti yang sah;

b. dan atas keterbuktian dengan sekurang-kurangnya dua alat bukti yang sah, hakim memperoleh keyakinan bahwa tindak pidana benar-benar terjadi dan terdakwalah yang bersalah melakukannya (Erwin Asmadi, 2013, h. 73).

Kekuatan alat bukti keterangan ahli dimana suatu keterangan ahli baru mempunyai nilai pembuktian, bila ahli tersebut disumpah terlebih dahulu sebelum memberikan keterangan, dengan bersumpah baru mempunyai nilai sebagai alat bukti. Apa yang diterangkan oleh seorang ahli adalah merupakan kesimpulan-kesimpulan dari suatu keadaan yang diketahui sesuai dengan keahliannya, atau dengan kata lain merupakan penilaian atau penghargaan tentang suatu keadaan. Hal ini berbeda dengan keterangan seorang saksi, yang justru dilarang untuk memberikan kesimpulan-kesimpulan, karena saksi hanyalah merupakan pengungkapan kembali fakta-fakta yang oleh saksi dilihat, didengar dan dialami sendiri (Hari Sasangka dan Lily Rosita, 2003, h. 60).

Seorang korban yang mengalami tindak pidana kekerasan psikis dalam rumah tangga, ketika sudah masuk tahap penyidikan maka akan dilakukan pemeriksaan terhadap korban 
DE IEGA LATA

Jurnal Ilmu Hukum

FAKULTAS HUKUM UMSU

dengan menggunakan seorang ahli. Ahli yang dimaksud dalam hal ini adalah seorang Dokter psikiater yang merupakan profesi Dokter spesialistik yang memiliki spesialisasi dalam diagnosis dan penanganan gangguan emosional yang menangani masalah gangguan jiwa berat maupun ringan dengan menggunakan ilmu psikiatri (ilmu kedokteran jiwa).

Ilmu Kedokteran Jiwa (Psikiatri) atau psikiatri umum yang mengkhususkan diri pada hal-hal gangguan kejiwaan dengan kasus tindak pidana oleh sebab penyakit jiwa/terganggu jiwanya, terganggu kepribadiannya (R. Soeparmono, 2016, h. 28). Namun dalam kasus ini, yang dibuktikan bukanlah tersangka/terdakwanya, namun sang korban yang mengalami kekerasan psikis, apakah akibat dari kekerasan psikis tersebut sang korban mengalami gangguan jiwa atau tekanan batin dan mental. Dampak yang ditimbulkan akibat kekerasan psikis adalah mengalami gangguan jiwa atau mental dan yang bisa mengatakatan seseorang mengalami kegonjangan dalam jiwanya merupakan harus seorang yang ahli dibidangnya yaitu Dokter (ahli) Psikiater, penyidik tidak bisa melihat kalau korban mengalami kekerasan psikis, dan kekerasan psikis tidak bisa dilihat secara kasat mata, oleh karena itu penyidik meminta bantuan kepada Dokter (ahli) Psikiater untuk melakukan pemeriksaan terhadap sikorban.

Menentukan korban mengalami kekerasan psikis maka "Psikiater melakukan pemantauan dan penelitian terhadap si korban dan waktu yang dibutuhkan untuk memeriksa korban psikis tidak cukup dengan waktu yang singkat, namun dibutuhkan waktu yang lama, paling lama waktu yang dibuthkan paling sedikit 1 minggu dengan melakukan wawancara, kemudian psikiater yang menyatakan sikorban mengalami gangguan psikis, jika sikorban dikatakan mengalami gangguan, maka akan ditentukan oleh psikiater tinggkatan berapa gangguan psikis yang dialami korban, dikategorikan gangguan ringan, sedang atau berat".

Membuktikan KDRT secara psikis mempunyai proses yang khusus dibandingkan dengan KDRT secara fisik maupun seksual, karena "KDRT secara psikis ini harus dibantu oleh seorang Dokter atau ahli psikiater dalam proses pembuktiannya untuk menentukan benar atau tidaknya seorang korban mengalami suatu tindak pidana kekerasan psikis.Kedudukan psikiater dalam membuktikan kekerasan psikis korban KDRT pada tingkat penyidikan berbicara tentang posisi seseorang psikiater dan kegunaan psikiater sebagai apa dalam membuktikan kekerasan psikis korban KDRT pada tingkat penyidikan”.

Kehadiran seorang ahli dalam memberikan keterangan di tingkat penyidikan dalam terjadinya suatu tindak pidana menjadi sangat penting dalam semua tahap-tahap penyidikan, baik dalam tahap penyelidikan, penindakan, pemeriksaan maupun penyerahan berkas perkara kepada penuntut umum hingga ke tahap persidangan. Tanpa kehadiran seorang ahli dalam memberikan atau menjelaskan suatu masalah akan dapat dibayangkan bahwa penyidik akan mengalami kesulitan dalam usaha mengungkapkan suatu tindak pidana (Andi Sofyan dan Abdul Asis, 2014, h. 246).

Kedudukan psikiater dalam membuktikan kekerasan psikis korban KDRT adalah sebagai 'kunci', karena hanya psikiater yang bisa mengatakan bahwa korban memang benar mengalami kekerasan psikis, sedangkan alat bukti yang lainnya sebagai bukti pendukung dan sebagai petunjuk, sehingga keterangannya akan dimintai di setiap tahap pemeriksaan dari mulai penyidikan, penuntunan dan persidangan, yang dimana keterangan yang diberikan 
Jurnal Ilmu Hukum

FAKULTAS HUKUM UMSU
Peran Psikiater Dalam...(Erwin Asmadi)

Volume 3 Nomor 1, Januari-Juni 2018, 39-51

DOI: https://doi.org/10.30596/dll.v3i1.3136

seorang Dokter Psikiater tersebut menjadi salah satu alat bukti yang sah yaitu 'keterangan ahli'.

Pasal 184 Ayat 1 KUHAP menyebutkan alat bukti yang sah ialah keterangan saksi, keterangan ahli, surat, pentunjuk dan keterangan terdakwa. Macam-macam alat bukti tersebut di atas, yang perlu diterangkan adalah alat bukti yang berupa 'keterangan ahli'. Untuk mengetahui dan membuktikan seorang korban mengalami kekerasan psikis, diperlukan ahli (pakar) dalam bidang tersebut. Di muka persidangan saksi ahli tersebut di atas, khusus dimaksud sebagai ilmuan yang melakukan pemeriksaan dan mengemukakan pendapat. Oleh karena itu untuk istilah 'ahli' (expert) sebenarnya dapat dibagi dalam 3 (tiga) macam ahli yang biasanya terlibat dalam suatu proses peradilan. (R. Soeparmono, 2016, h. 58):

a. Ahli (deskundige). Orang ini hanya mengemukakan pendapatnya tentang suatu persoalan yang ditanyakan kepadanya, tanpa melakukan suatu pemeriksaan. Contoh ahli demikian, adalah Dokter Spesialis Kejiwaan (Dokter Psikiater), yang diminta pendapatnya tentang ilmu yang dimiliki Dokter tersebut seorang korban yang sedang mengalami tekanan mental atau batin akibat mengalami kekerasan psikis.

b. Saksi ahli (getuige deskundige). Orang ini menyaksikan barang bukti atau "saksi diam", melakukan pemeriksaan dan mengemukakan pendapatnya, misalnya seorang Dokter yang melakukan pemeriksaan mayat, jadi ia menjadi saksi, karena menyaksikan barang bukti dan kemudian menjadi ahli, karena mengemukakan pendapatnya tentang sebab kematian (meninggalnya) orang itu.

c. Zaakkundige. Orang yang menerangkan tentang sesuatu persoalan yang sebenarnya dapat dipelajari sendiri oleh Hakim, tetapi akan memakan banyak waktu.

Dasar-dasar hukum tentang peranan keterangan ahli (pakar) itu bagi kelengkapan alat bukti dalam perkara pro yustisia dan pemeriksaan di sidang pengadilan, amat membantu dalam usaha untuk menambah keyakinan Hakim dalam hal pengambilan putusan. Di dalam HIR dahulu, alat bukti keterangan ahli tidak secara tegas dicantumkan sebagai alat bukti sah, tetapi hanya disebutkan dan tersisip di dalam pasal-pasal lain di luar Pasal 295 HIR. Pasalpasal yang menyebut tentang keterangan ahli atau Dokter (ahli) tersebut antar lain terdapat dalam Pasal 68, Pasal 69, Pasal 70, Pasal 83b, Pasal 286, Pasal 287, Pasal 306, dan Bab X HIR tentang saksi yang berlaku juga bagi orang ahli.

Menurut Pasal 1 angka 28 KUHAP diterangkan bahwa yang dimaksud dengan 'keterangan ahli' adalah keterangan yang diberikan oleh seorang yang memiliki keahlian khusus tentang hal yang diperlukan untuk membuat terang suatu perkara pidana guna kepentingan pemeriksaan (di sidang pengadilan). Sedangkan dasar-dasar hukum bagi bantuan ahli terdapat dalam Pasal 7 Ayat 1 sub h, Pasal 120, Pasal 132, pasal lainnya yang disebut di muka pada KUHAP dalam tahap penyidikan.

Pengertian keterangan ahli sebagaimana rumusan Pasal 1 angka 28 KUHAP (pengertian umum), yaitu mereka yang secara khusus diperlukan untuk menerangkan sesuatu hal dan memenuhi syarat (R. Soeparmono, 2016, h. 81), yakni:

a. Keterangan yang diberikan oleh 'seorang'. Keterangan ahli tersebut diberikan oleh orang dan bukan suatu badan hukum atau yayasan dan sebagainya. Kemungkinan lain adalah, bahwa seseorang itu dapat terdiri lebih dari seorang atau dapat pula beberapa orang yang merupakan keterangan Tim (majelis). 
Jurnal Ilmu Hukum

FAKULTAS HUKUM UMSU

b. Yang memilili 'keahlian khusus'. Keterangan dari orang tersebut harus benar-benar memiliki kemampuan ilmu atau pengetahuan dan pengalamannya dan/atau keahlian yang khusus, jadi bukan oleh orang yang hanya memiliki keahlian umum. Orang ahli spesialis yang mempunyai atau memiliki keahlian khusus tersebut akan memberikan pendapatnya yang sebaik-baiknya yang dikemukakan secara benar atau yang sebenarnya, sehingga didapatkan proses atau hasil yang sebaik-baiknya.

c. Tentang 'sesuatu hal, yang diperlukan'. Yang diterangkan itu adalah tentang sesuatu hal atau keadaan peristiwa yang diperlukan saja dalam suatu perkara pidana, sehingga tidaklah meliputi hal-hal atau keadaan-keadaan yang sudah jelas ataupun yang oleh hakim sudah diketahui.

d. Untuk membuat 'terang' perkara pidana tersebut. Agar sesuatu hal atau keadaan yang diperlukan untuk diketahui oleh Hakim tersebut akan membuat perkara pidana itu menjadi lebih 'jelas', sehingga akan nampak dari suatu hal atau keadaan yang semula 'tidak jelas' menjadi 'jelas' yaitu perihal tentang terbuktinya sesuatu hal atau keadaan perkara pidana itu.

e. Guna 'kepentingan pemeriksaan'. Kegunaan, manfaat atau urgensinya bagi kepentingan pemeriksaan perkara, sebab bilamana tidak ada kegunaan, manfaat atau urgensinya bagi kepentingan pemeriksaan, maka keterangan ahli tidaklah diperlukan.

Peran psikiater sebagai ahli sangat dibutuhkan guna mengungkapkan bahwa memang benar seorang korban tindak pidana kekerasan psikis tersebut mengalami KDRT dan apabila diduga kuat akibat yang ditimbulkan dari kekerasan psikis tersebut mengakibatkan korban menderita gangguan atau penyakit jiwa yang menyerang psikis/batin/mentalnya. Istilah yang dipergunakan pada tingkat pemeriksaan penyidikan dalam kewenangannya untuk meminta kepada ahli kedokteran dinamakan keterangan ahli (deskundige verklaring) (R. Soeparmono, 2016, h. 74).

Peran lainnya dari Dokter Ahli Psikiater dalam membantu menjernihkan suatu perkara adalah dengan mengeluarkan suatu surat atau keterangan tertulis. Keterangan tersebut merupakan hasil dari pemeriksaan terhadap korban yang mengalami kekekerasan psikis dalam rumah tangga. Surat hasil pemeriksaan tersebut berupa visum et repertum yang dikenal dalam dunia psikiater dengan sebutan visum et repertum pshiciatricum.

Visum et repertum adalah laporan atau keterangan tertulis dari seorang Dokter (ahli) atas perintah atau permintaan tertulis dari yang berwajib atau berwenang terhadap hasil pemeriksaan, yaitu yang dilihat dan diketemukan berdasarkan pengetahuan sebaik-baiknya menurut bidang keahliannya untuk peradilan (Pro Justisia) dengan mengingat sumpah atau janji pada waktu menerima jabatan (R. Soeparmono, 2016, h. 3).

Visum et repertum psychiatricum atau visum et repertum psikiatrik yaitu yang dikenal dalam bidang ilmu kedokteran jiwa atau psikiatri. visum et repertum psychiatricum sebagai salah satu aspek peranan ahli psikiater dan/atau adalah satu aspek keterangan ahli, maka keterkaitan antara keduanya tidak dapat dipisahkan. Keterangan ahli yang tertuang dalam suatu laporan hasil pemeriksaaan adalah perwujudan hasil-hasil yang dibuat berdasarkan atas ilmu dan teknik serta pengetahuan dan pengalaman yang sebaik-baiknya dari ahli itu (R. Soeparmono, 2016, h. 16).

Suatu keterangan pskiater yang berupa visum et repertum psychiatricum dan merupakan keterangan Dokter, disitu merupakan suatu kesaksian tertulis, baik dalam perkara perdata 
DE LEGA LATA

Jurnal Ilmu Hukum

FAKULTAS HUKUM UMSU
Peran Psikiater Dalam...(Erwin Asmadi)

Volume 3 Nomor 1, Januari-Juni 2018, 39-51

DOI: https://doi.org/10.30596/dll.v3i1.3136

maupun pidana dan dibuat atas permintaan Hakim (pengadilan) dengan mengingat sumpah jabatannya (sumpah Dokter), sedangkan 'suatu keterangan Dokter' adalah suatu keterangan yang diberikan oleh Dokter atas permintaan Jaksa, Polisi atau pejabat lain dalam proses pemeriksaan penyidikan dan penuntutan, sehingga menurut KUHAP, Visum et repertum psychiatricum juga merupakan keterangan ahli yang termasuk alat bukti yang sah (R. Soeparmono, 2016, h. 29).

Keterangan ahli sebagaimana dimaksud dalam Pasal 186 KUHAP, menyangkut korban KDRT yang menderita kekerasan psikis, hanya dapat dilakukan oleh Ahli kedokteran jiwa (ahli psikiatri), kecuali dalam hal pembuatan visum et repertum psychiatricum, maka kedudukan dari visum et repertum psychiatricum pada umumnya, adalah merupakan aspek dari keterangan ahli, dalam hukum pembuktian (R. Soeparmono, 2016, h. 37).

\section{KESIMPULAN DAN SARAN Kesimpulan}

Berdasarkan uraian di atas, maka bentuk Kekerasan Dalam Rumah Tangga (KDRT) menurut UU PKDRT meliputi kekerasan fisik, kekerasan psikis, kekerasan seksual, penelantaran rumah tangga, lingkup rumah tangga tersebut antara lain: Suami, istri, dan anak; Orang yang mempunyai hubungan keluarga dengan Suami, istri, dan anak karena hubungan darah, perkawinan, persusuan, pengasuhan, dan perwalian, yang menetap dalam rumah tangga; dan/atau Orang yang bekerja membantu rumah tangga dan menetap dalam rumah tangga tersebut.

Peran psikiater dalam pembuktian kekerasan psikis korban tindak pidana kekerasan dalam rumah tangga adalah memberikan Keterangan Ahli yakni keterangan yang diberikan oleh seorang yang memiliki keahlian khusus tentang hal yang diperlukan untuk membuat terang suatu perkara pidana guna kepentingan pemeriksaan (di sidang pengadilan) sehingga menjadi salah satu alat bukti yang sah. Peran lainnya dari Dokter Ahli Psikiater dalam membantu menjernihkan suatu perkara adalah dengan mengeluarkan suatu surat atau keterangan tertulis. Keterangan tersebut merupakan hasil dari pemeriksaan terhadap korban yang mengalami kekekerasan psikis dalam rumah tangga. Surat hasil pemeriksaan tersebut berupa visum et repertum yang dikenal dalam dunia psikiater dengan sebutan visum et repertum pshiciatricum.

\section{Saran}

Masalah utama penegakan hukum terhadap tindak pidana kekerasan psikis pada Kekerasan dalam Rumah Tangga (KDRT) ini adalah enggannya masyarakat untuk melaporkan kejadian atau peristiwa. Memberitahukan masalah keluarga masih dianggap sebagai rahasia bahkan aib yang harus ditutupi sehingga proses penegakan hukumnya menjadi tidak berjalan dengan baik. Sehingga dalam penerapannya perlu mengedepankan 'ultimum remedium' sebagai alternatif terbaik dalam penyelesaian perkara KDRT. 


\section{DAFTAR PUSTAKA}

Asmadi, Erwin. (2013). Pembuktian Tindak Pidana Teroris (Analisa Putusan Pengadilan Pada Kasus Perampokan Bank CIMB Niaga Medan). Medan: PT. Sofmedia.

Brahmana, H.S. (2015). Hukum Acara Pidana. Medan: Ratu Jaya.

Euy, Asep Thea. (2017). Kekerasan Dalam Rumah Tangga. Diakses pada tanggal 16 Desember 2017 melalui www.barhoya.blogspot.co.id

KDRT. (2018). Diakses pada tanggal 3 Maret 2018 dari digilib.unila.ac.id

Khaleed, Badriyah. (2015). Penyelesaian Hukum KDRT. Yogyakarta: Pustaka Yustisia.

Linawati, Ester. (2017). Dampak Psikis Kekerasan dalam Rumah Tangga. Diakses pada tanggal 20 Desember 2017 melalui www.esterlianawati.wordpress.com

Pengertian Psikiater. (2018). Diakses pada tanggal 3 Maret 2018 melalui id.wikipedia.org

Saanin, Hasan Basri. (1982). Psikiater dan Pengadilan. Bandung: Ghalia Indonesia.

Sasangka, Hari., \& Rosita, Lily. (2003). Hukum Pembuktian dalam Perkara Pidana. Bandung: Mandar Maju.

Soeparmono, R. (2016). Keterangan Ahli \& Visum Et Repertum dalam Aspek Hukum Acara Pidana. Bandung: Mandar Maju.

Sofyan, Andi., \& Asis, Abdul. (2014). Hukum Acara Pidana. Jakarta: P.T. Tambra Raya.

Undang-Undang Nomor 23 Tahun 2004 tentang Penghapusan Kekerasan Dalam Rumah Tangga.

Undang-Undang Nomor 8 Tahun 1981 tentang Hukum Acara Pidana.

Waluyo, Bambang. (2014). Victimologi Perlindungan Saksi dan Korban. Jakarta: Sinar Grafika. 